\title{
PENGUKURAN KESEIMBANGAN LINTASAN PRODUKSI SABUK KOPLING MOBIL
}

\author{
Akhsani Nur Amalia ${ }^{1}$, Darmawan Yudhanegara ${ }^{1 *}$, \\ Agung Gumelar ${ }^{1}$

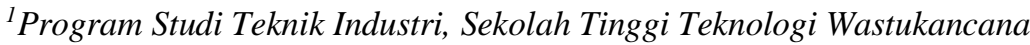 \\ Jln. Cikopak No. 53, Purwakarta, Jawa Barat \\ *Penulis Korespondensi : darmawan@stt-wastukancana.ac.id
}

\begin{abstract}
Time efficiency in production is very supportive of fulfilling consumer demand. The line balancing problem can be solved by taking measurements first. This measurement aims to determine the parameters that cause an imbalance in the production line. The first step to minimize reducing idle time production is getting the balance indikator of line production. Rank Postional Weight is heuristic's systematic approach method is used to measure the balance of the car CVT belt production line in a grinding machine to get imbalance result. The measurement results show that it is not good with a smothness index of 130.48 minutes, the product produced is only $97.5 \%$ of the set target, the performance of the work station is $80.56 \%$. Improvements in several work stations in order to improve the balance of the trajectory, namely in visual checks, smoothing surfaces and shapes, measuring products by rearranging the order.
\end{abstract}

Keywords: Automotif, Balancing, Heuristic, Ranking

\section{Pendahuluan}

Dalam sistem manufaktur terdapat adanya masalah ketidakseimbangan lintasan produksi. Masalah ini mengakibatkan penumpukan pekerjan dalam proses pada stasiun kerja tertentu didalamnya. Apabila terjadi penumpukan sehingga waktu pengerjaan produksi menjadi tertunda, sehingga tidak bisa memenuhi kebutuhan pelanggan sesuai waktu pemesanan (Helgeson and Birnie 1961). Masalah keseimbangan menjadi bagian dari keseluruhan masalah produksi, apalagi terjadi kelambatan sehingga menjadi masalah produksi lainnya timbul.

Kajian pengukuran yang dilakukan pada keseimbangan lintasan produksi untuk produk sabuk kopling sama dengan keseimbangan produksi lainnya pada prinsipnya. Lintasan yang dikaji pada mesin gerinda dan mesin freis yang terdiri dari beberapa pengerjaan stasiun kerja. Siklus pengerjaan dalam lintasan ini sebesar 180 jam untuk setiap stasiun pengerjaan. Jumlah statsiun kerja yang sedang berjalan sebanyak 9 dari lintasan awal sampai lintasan akhir.

Tujuan peneltian ini adalah untuk mengukur parameter yang ada pada lintasan produksi sehingga terjadinya ketidakseimbangan, yang berguna untuk tindakan selanjutnya untuk melakukan perancangan ulang lintasan sehingga diperoleh seimbang. Pertimbangan pada pengukuran keseimbangan lintasan pada kapasitas produksi (Kayar and Akalin 2014). Pengukuran merupakan bagian dari adanya perbaikan yang memungkinkan awal dari perancangan ekonomis (Yudhanegara 2021a).

Metode pembobotan peringkat posisi (rank positional weight) adalah salah satu metode heuristik untuk mengukur masalah keseimbangan 
lintasan. Metode ini dapat digunakan pada sistem produksi berbagai produk, seperti komponen onderdil mobil dalam (Ponda, Hardono, and Pikri 2019). Prinsip perhitungannya dengan pendekatan sistematis (Yudhanegara 2021b).

Lokasi penelitian merupakan perusahaan yang memproduksi onderdil

\section{Metodologi Penelitian}

Metodologi penyelesaian pengukuran ini dengan menggunakan prinsip berpusat pada metode yang digunakan, sehingga urutan penyelesaiannya pengukuran berdasarkan langkah-langkah pada metode.

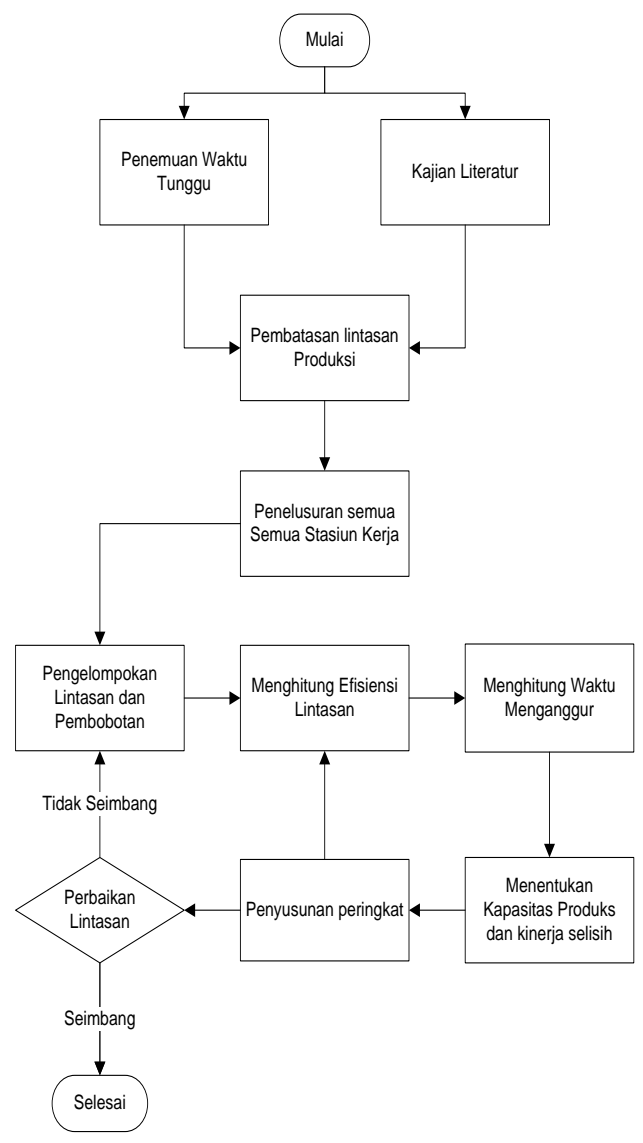

Gambar 1. Metodologi Pengukuran

Penelitian pengukuran ini dilaksakan berdasarkan adanya pengamatan pada departemen yang memiliki keseimbangan lintasan yang cukup besar dengan adanya penumpukan kendaraan roda empat dengan kapasitas yang sangat besar. Lintasan yang diukur pada salah satu departemen yaitu mesin gerinda. Departemen ini terdiri dari sembilan stasiun kerja. Jarak antar stasiun kerja dibatasi dengan beda ruangan.

produksi onderdil dalam proses lintasan produksi. Sebelum melakukan optimalisasi pada lintasan, dilakukan pengukuran keseimbangan lintasan terlebih dahulu.

Penelitian bertujuan untuk menemukan nilai-nilai parameter yang dapat dipertimbangkan untuk analisis keseimbangan lebih lanjut. Analisis keseimbangan bertujuan untuk mengambil keputusan dalam memperkirakan lintasan produksi yang dapat lebih diseimbangkan.

Rank Position Weight menjadi alat yang digunakan untuk mengukur keseimbangan produksi pada kajian mesin gerinda memproduksi sabuk kopling mobil. Secara metodologi, metode ini dengan prinsip penelusuran secara sistematis terhadap semua stasiun kerja pada lintasan yang dikaji. Pendekatan yang digunakan dengan formulasi dengan prinsip pembobotan peringkan posisi pada semua stasiun kerja.

\section{Hasil dan Pembahasan}

Penelitian ini memperoleh
beberapa temuan berdasarkan parameter yang telah diukur. Pada kajian mesih gerinda yang tersusun yang ditentukan berdasarkan lamanya waktu setiap stasiun kerja sehingga menjadi tidak seimbang.

\section{Operasi Kerja}

Operasi pendahulu $(O P)$, nama operasi $(O)$ dan kuantitas produksi $(Q)$. Operasional kerja mesin gerinda untuk setiap pekerjaannya didefiniskan. Namasama operasional kerja dilakukan berdasarkan susunan dalam standar 
operasi prosedur yang ada di perusahaan yang dikaji.

Tabel 1. Operasi Kerja Eksisting

\begin{tabular}{clc}
\hline OP & \multicolumn{1}{c}{$O$} & $Q$ \\
\hline$A$ & Visual Check & 970 \\
$B$ & Surface Grinding & 940 \\
$C$ & Machining & 840 \\
$D$ & Coating & 670 \\
$E$ & Measurement & 540 \\
$F$ & Visual Check & 785 \\
$G$ & Surface Grinding & 755 \\
$H$ & Forming grinding & 665 \\
$I$ & Shot Blast & 555 \\
$J$ & Measurement & 540 \\
$K$ & Dies Assembling & 450 \\
& Press Machine & 320 \\
& Finishing & Material and \\
$M$ & Machine Set up & 290 \\
\hline
\end{tabular}

\section{Pengelompokan Operasi Kerja}

Pengelompokan kerja dapat disusun berdasarkan susunan stasiun kerja (WS), waktu siklus $(C T)$, nama operasi $(O)$, kecepatan kerja $(W R)$, waktu menunggu (I), dan efisiensi lintasan (LE). Setiap stasiun kerja memiliki waktu kerja yang berbeda-beda dan waktu mengganggur, sehingga efisiensi lintasan cukup rendah.

Mesin gerinda tersusun yang cukup berdekatan sekitar 5 meter. Sehingga waktu antar mesin yang menyebabkan kelambatan dapat diabaikan. Susunan kerja yang tidak efisien yang mejadi perhatian dalam pengukuran keseimbangan lintasan.
Tabel 2. Efisiensi Lintasan

\begin{tabular}{|c|c|c|c|c|c|}
\hline$W S$ & $C T$ & $O$ & $W R$ & $I$ & $L E$ \\
\hline \multirow{2}{*}{1} & \multirow{2}{*}{180} & $A$ & 30 & \multirow{2}{*}{50} & \multirow{2}{*}{72} \\
\hline & & $B$ & 100 & & \\
\hline 2 & 180 & $C$ & 170 & 10 & 94 \\
\hline \multirow{2}{*}{3} & \multirow{2}{*}{180} & $F$ & 30 & \multirow{2}{*}{60} & \multirow{2}{*}{67} \\
\hline & & $G$ & 90 & & \\
\hline 4 & 180 & $D$ & 130 & 50 & 72 \\
\hline \multirow{2}{*}{5} & \multirow{2}{*}{180} & $H$ & 110 & \multirow{2}{*}{55} & \multirow{2}{*}{69} \\
\hline & & $I$ & 15 & & \\
\hline \multirow{2}{*}{6} & \multirow{2}{*}{180} & $E$ & 90 & \multirow{2}{*}{0} & \multirow{2}{*}{100} \\
\hline & & $J$ & 90 & & \\
\hline \multirow{2}{*}{7} & \multirow{2}{*}{180} & $K$ & 130 & \multirow{2}{*}{20} & \multirow{2}{*}{89} \\
\hline & & $L$ & 30 & & \\
\hline 8 & 180 & $M$ & 180 & 0 & 100 \\
\hline 9 & 180 & $N$ & 110 & 70 & 61 \\
\hline
\end{tabular}

Penyusunan urutan kerja berdasarkan stasiun kerja dapat mudah untuk diukur dengan metode heuristik.

\section{Menghitung Efisiensi Lintasan}

Line eficiency (LE) dapat dihirung dengan menggunakan rumus yang dibentuk dari data dihitung dengan jumlah stasiun kerja $(k)$, waktu operasi $\left(T_{e}\right)$ dan waktu siklus $(C T)$ yakni

$$
\begin{aligned}
& L E=\frac{\Sigma T_{e}}{k \times C T} \\
& L E=\frac{1,305}{9 \times 180} \\
& L E=80,56
\end{aligned}
$$

Efisien lintasan diperoleh sebesar $80,56 \%$. 
Waktu Keterlambatan Seimbang

$$
\begin{aligned}
& \text { Balance delay } \\
& \text { merupakan } \\
& \text { keseimbangan artinya waktu } \\
& \text { menganggur suatu stasiun kerja } \\
& \text { sehingga membuat adanya } \\
& \text { penumpukan. Data dihitung dengan } \\
& \text { jumlah stasiun kerja }(k) \text {, waktu } \\
& \text { operasi }\left(T_{e}\right) \text { dan waktu siklus }(C T) \\
& \text { yakni } \\
& B D=\frac{(k \times C T)-\Sigma T_{e}}{k \times C T} \\
& B D=\frac{315}{1,620} \\
& B D=19,44
\end{aligned}
$$$$
\text { keterlambatan }
$$

Waktu keterlambatan keseimbangan menunjukan sebesar 19,44\% .

\section{Kapasitas Produksi}

Penentuan kapasitas produksi $(P C)$ per lot per tahun, dapat dicapai dari metode yang digunakan, dengan membagi ketersediaan waktu kerja (WTA) dengan waktu siklus (CT) dengan formulasi

$$
\begin{aligned}
& P C=\frac{W T A}{C T} \\
& P C=\frac{345,800}{180} \\
& P C=1921,1
\end{aligned}
$$

Kapasitas produksi lot per tahun dihitung dengan per tahun 260 hari memberikan selisih yang cukup besar sebesar dari kapasitas produksi perencanan dengan kapasitas produksi perbaikan.

$$
P C=C P_{P}-C P_{I}
$$

$$
P C=1971-1921
$$

$$
P C=49
$$

\section{Indeks Kelancaran}

Smoothness Index (SI) yang menunjukan adanya kelancaran pada kajian penelitian ini dapat diperoleh parameter-parameter dari metode yang digunakan yakni sebagai berikut uraiannya.

Tabel 3. Indeks kelancaran

\begin{tabular}{rrr}
\hline$W S$ & \multicolumn{1}{l}{$I$} & \multicolumn{1}{l}{$I^{2}$} \\
\hline 1 & 50 & 2500 \\
2 & 10 & 100 \\
3 & 60 & 3600 \\
4 & 50 & 2500 \\
5 & 55 & 3025 \\
6 & 0 & 0 \\
7 & 20 & 400 \\
8 & 0 & 0 \\
9 & 70 & 4900 \\
\hline$\sqrt{\sum(I)^{2}}$ & & 17,025 \\
\hline \multicolumn{4}{c}{$S I$} & & 130.48 \\
\hline
\end{tabular}

Dari tabel 2, diperoleh dengan menggunakan formulasi matematika bahwa waktu tunggu (I) dengan formulasi waktu siklus (CT) dikurangi dengan formulasi

$$
I=C T-T_{e}
$$

Sehingga diperoleh smoothing Index (SI) sebagai berikut

$$
S I=\sqrt{\Sigma(I)^{2}}
$$




$$
\begin{gathered}
S I=\sqrt{17,025} \\
S I=130,48
\end{gathered}
$$

\section{Hasil Pencapaian Pengukuran}

Hasil pengukuran dari keseimbangan lintasan diperoleh parameter sehingga ditemukan stasiun kerja yang terjadi penumpukan. Dengan cara pembobotan posisi kecepatan diperoleh ukuran yang tepat sehingga seimbang pada kuantitas perbaikan $\left(Q^{*}\right)$. Hasilnya diperoleh sebagai berikut.

\begin{tabular}{|c|c|c|c|}
\hline$O P$ & $Q$ & $Q^{*}$ & $Q-Q^{*}$ \\
\hline$A$ & 970 & 970 & - \\
\hline$B$ & 940 & 940 & - \\
\hline$C$ & 840 & 840 & - \\
\hline$F$ & 670 & 785 & (115) \\
\hline$G$ & 540 & 755 & 215 \\
\hline$D$ & 785 & 670 & (115) \\
\hline$H$ & 755 & 665 & 90 \\
\hline$I$ & 665 & 555 & 90 \\
\hline$E$ & 555 & 540 & 15 \\
\hline$J$ & 540 & 540 & - \\
\hline$K$ & 450 & 450 & - \\
\hline$L$ & 320 & 320 & - \\
\hline$M$ & 290 & 290 & - \\
\hline
\end{tabular}

Tabel 4. Perbaikan Kuantitas Produksi

Selisih kuantitas produk yang dihasilkan dari seluruh stasiun kerja hanya 6 stasiun kerja.

\section{Kesimpulan}

Hasil dari penelitian ini memperoleh beberapa temuan yaitu

- Pengukuran pada keseimbangan lintasan produksi khususnya untuk produk onderdil automotif yang terjadi adanya subkontrak produk setengah jadi ke subkontraktor luar tidak dapat dikendalikan.

- $\quad$ Pengukuran bersifat sistematis yang membuat hasil tidak diperoleh maksimal, perlu adanya pengukuran secara sistemik.

- Pengukuran berdasarkan menghitung angka baku, perlu ditinjau ulang. Artinya diperlukan alat khusus dalam proses pengukuran pada subsistem yang dikaji.

\section{Daftar Pustaka}

Helgeson, W.P., and D.P. Birnie. 1961. "Assembly Line Balancing Using the Ranked Positional Weight Technique." Journal of Industrial Engineering,.

Kayar, Mahmut, and Mehmet Akalin. 2014. "A Research on the Effect of Method Study on Production Volume and Assembly Line Effeciency." Tekstil ve Konfeksiyon 24 (2).

Ponda, Henri, Joko Hardono, and Sofi Khaerul Pikri. 2019. "ANALISA KESEIMBANGAN LINTASAN PRODUKSI PADA PEMBUATAN RADIATOR MITSUBISHI PS 220 DENGAN METODE RANKED POSITIONAL WEIGHT (RPW)." Journal Industrial Manufacturing 4 (1). https://doi.org/10.31000/jim.v4i1.1 251.

Yudhanegara, Darmawan. 2021a. Pengantar Ilmu Ekonomi Untuk Teknik Dengan Menggunakan Insighmaker. 1st ed. Malang: Ahli media press. 
2021b. Riset Operasi

Manajemen Transportasi. 1st ed.

Malang: Ahli media press. 